\title{
The Aesthetic Dimension of Passion
}

\author{
SEBASTIAN GARDNER
}

\begin{abstract}
This paper is stimulated by and indebted to a study by Charles Altieri of the ways in which affect is present and articulated in art and literature, which, he argues, hold significance for the philosophy of emotion. I focus on Altieri's thesis that affective states may have aesthetic qualities and value. I pursue this notion first with reference to Nietzsche's attempt to recruit affect as a means of countering Schopenhauer's pessimism. I then attempt to show the coherence of the (on the face of it problematic) notion that passion may exhibit an aesthetic dimension, drawing on Richard Wollheim's account of certain ideas in psychoanalytic theory, for which I suggest precedents in the history of philosophy.
\end{abstract}

The hypothesis I want to explore is that passion has an aesthetic dimension, and I should begin by saying how I intend this to be understood. ${ }^{1}$ The proposal is that passion is capable of affording a type of satisfaction and answering to a type of interest which merits being described as aesthetic, as distinct from the cognitive and ethical interests which are also in play in our awareness of our emotional states. This is not to say that every instance of passion is aesthetically rewarding, which is clearly not the case, but that passion per se holds aesthetic potential. This is something different from saying that passion provides the material for art and other aesthetic constructions, as many theories of art tell us. It is also distinct from the claim that people in states of passion can be viewed aesthetically, or made the topic of aesthetically interesting representations. Again, it is distinct from the observation that passions are capable of giving the worldly things towards which they are directed an emotional colouring which makes them aesthetically significant. The idea, to repeat, is that passion has a reflexive aesthetic potential on the inside, i.e. for the one who undergoes it, and that this arises from its internal constitution and not from the imposition of anything external to it, though undoubtedly special conditions are required for the potential to be realized.

The idea is taken from a book by Charles Altieri, a distinguished critic of literary and pictorial modernism: The Particulars of Rapture: An Aesthetics of the Affects (Ithaca, NY: Cornell University Press, 2003). The debt is plain from the sub-title. Altieri argues

\footnotetext{
${ }^{1}$ I employ throughout the familiar distinction of 'passions' or 'emotions' (terms used interchangeably) from 'episodes of feeling'. When full generality is required I talk or 'affect' or 'affective state'. What needs to be said regarding the other key term, viz., 'aesthetic', will emerge in due course.
} 
that reflection on the literary and visual arts exposes the narrowness of philosophical discussion of emotion, and shows how we may correct for it. ${ }^{2}$ The limitation of philosophy's scope is reflected in the way that that the relatively stable and enduring affective objects on which it typically fixes are the most obvious, easily pin-downable items in the field of affect, the equivalent of epistemology's 'medium-sized dry goods'. To concentrate on these, however, is like trying to map the geography of a country by attending only to its mountains. The narrowness has various causes. In the case of early modern writing, it results from the dominance of moral and therapeutic concerns in discussion of the passions, while in contemporary work, it arises from the way in which analysis standardly takes the ascriptions of common sense psychology ('proud of -', 'glad that - ', 'envious of -', etc.) as its starting point. Altieri's claim is that art, on account of its relative autonomy - its independence from the explanatory and normative constraints of common sense psychology $y^{3}$ affords access to the true complexity of affective phenomena, which philosophical reflection, unassisted by art, overlooks. ${ }^{4}$

I will cite one of Altieri's examples in order to float the main idea, and I hope show something of its appeal, but I am not going to go into the detail of Altieri's discussion, although there is much of interest in his attempt to furnish philosophy with a new vocabulary and grammar for the affects. My aim instead is to consider the idea in more $a$ priori respects and show its precedents in the history of philosophy. The discussion is structured as follows. After starting with Altieri, I will suggest that a version of the idea is present in Nietzsche, and that it forms a key part of his reply to Schopenhauer. My purpose in dwelling on Nietzsche is to show how the idea allows itself to be developed into a strong form, which, whether or not it commands full philosophical assent, has (as it seems to me) strong appeal. That it has importance for Nietzsche does not mean however that he has a 'theory' of it as such, or that he provides the materials needed to answer the pure conceptual question of what makes it possible. So in the second half I will begin by stating the obvious puzzle surrounding the idea that passion can in any sense be aesthetic, and then in response

\footnotetext{
${ }^{2}$ Altieri's first chapter is titled accordingly: 'The Arts as a Challenge to Dominant Philosophical Theories of the Affects'.

${ }^{3}$ Henri Bergson makes a closely similar claim - that our affective taxonomies are crude, because they are guided by extraneous social and practical concerns, congealed in our common language - in Time and Free Will: An Essay on the Immediate Data of Consciousness, trans. F. L. Pogson (London: Allen \& Unwin, 1913), 128-133.

${ }^{4}$ Altieri's further motive has to do with critical practice: he favours a type of criticism at odds with prevailing tendencies in literary and art theory, which at best fail to register the presence of affect and at worst blind us to what matters in artworks.
} 
sketch a rudimentary general model of emotion, which, whether or not it stands up to scrutiny when considered in broader terms, coheres with the thesis I am exploring. ${ }^{5}$

\section{Altieri's proposal for an 'aesthetics of the affects'}

Altieri's striking thesis that affective states themselves are capable of exhibiting aesthetic qualities is distinct from the claim that affects are capable of arousing further, second-order feelings (as when I take pleasure in the fact that I feel painful compassion, because it signals my virtue, a model used in rationalist aesthetics). It is that states of passion can exhibit an aesthetic dimension in a way that bears comparison with that in which the configuration of elements in a painting or text can be aesthetically significant.

Here is how he explains the point in connection with central scenes in Othello, in which we are presented with, in his words, 'a situation where the aesthetic values involved clearly contrast with any instrumental analysis of the situation':

Suppose that someone were to take an aesthetic attitude toward his or her own jealousy - not simply as an observer of what being jealous involves but as an artist

\footnotetext{
${ }^{5}$ Since in this paper I make claims about emotion in general, it is is appropriate to say something about method in this area. One approach, prominent in early analytic discussion, is to begin by attempting to divide up the field of affect conceptually. Another is to start with a substantive thesis or specific theoretical proposal, invited by some particular form or aspect of emotion, leaving it to be seen how much territory has been either covered or left unaccounted for. There are reasons, some of which will emerge, for doubting that beginning with a conceptual taxonomy can avoid begging substantive questions, as there are also for thinking that the criteria for individuating affects are inherently fluid. A glance at Parts III and IV of Spinoza's Ethics confirms the heterogeneity of what may be subsumed under the heading of affect, and in Part III (Proposition 56, Proof) Spinoza asserts that 'there are necessarily as many kinds of pleasure, pain, love, hatred, etc. as there are kinds of objects by which we are affected' (Complete Works, trans. S. Shirley, ed. M. L. Morgan (Indianapolis: Hackett, 2002), 308). As Richard Wollheim puts it, the life of the emotions has a 'chaotic, overgrown, vegetal character' (On the Emotions (New Haven, NJ: Yale University Press, 1999), 117). One fundamental point concerns the extraordinary peculiarity of affect as a mental kind, given that its forms can vary so greatly as to embrace things as hugely different as, say, Othello's jealousy on the one hand and, on the other, the barely perceptible feelings of satisfaction that inflect the sight of a tidy desk or the hearing of cadence. It is hard to know how one might broach directly the question of what makes it possible for one mental kind - assuming there to be such - to be so protean. William James recognizes explicitly the way in which feeling functions as, at a stroke, the matter, substance, medium, framework, colouring, and glue of mental life, in The Principles of Psychology, Vol. I (London: Macmillan, 1890), Chs. 6-9.
} 
whose medium is one's own psyche. Most interpreters would find such revelling in jealousy at best a misjudgement, at worst lunacy. ${ }^{6}$

Altieri observes that critical commentary on Othello tends to adopt a cognitivist and therapeutic approach to the jealousy theme - in addition to pondering the psychological mystery of Iago, critics puzzle over how Othello can come to believe what he does about Desdemona, and ask what hidden motives and susceptibilities move him to do so. These are of course cogent questions, but Altieri proposes instead:

Suppose that, rather than judging how Othello goes wrong, we ask what might be of value in the experience he has by virtue of his going wrong. What modes of intensity and what kinds of involvement with others become possible? [...] Rather than stress the sense of pathos from the outside, an aesthetic attitude will ask how we can flesh out what it must have meant to him to put the case performatively, 'the pity of it, Iago, the pity of it'. For it seems that his awareness of the tragedy he is enacting gives him access to ecstatic states completely lost in a moral or strictly action-oriented account of his situation. ${ }^{7}$

What comes into view for Othello in his jealousy, Altieri suggests, is the full span of his love and need for Desdemona: its exalted quality, its erotic and bestial roots, his own powerlessness in face of its incomprehensibility, and the way it defies ethical and cognitive regulation. And this configuration is presented to Othello, not as a set of psychological or axiological truths into which it might be decomposed, but within the state as a whole. Altieri concludes, with reference to the final scene of the play:
All of this duality then makes possible a final affective intensity sustained by Othello's having to realize just how much distance there can be between the self who acts and the subsequent self who has to make an accurate assessment of how that action changed him. Othello's self-consciousness has no other life but to sound that difference. Therefore his final speeches resound with a sublime tension between the awareness of being reduced to a guilty thing and the expansive sense

\footnotetext{
${ }^{6}$ Altieri, The Particulars of Rapture, 20-21.

${ }^{7}$ Altieri, The Particulars of Rapture, 21.
} 
of how passion brought him to this impasse by for a short time letting him experience just how much the psyche can stake on being loved. ${ }^{8}$

The philosophical lesson to be drawn, as Altieri puts it, is that agents agents have interests in their own emotions that have nothing to do directly with the realization of desire, or achieving knowledge of a sort which could be detached and exported from the affective state itself; whatever knowledge is achieved in passion can be 'had', and held onto, only by remaining within the state:

An aesthetic orientation will focus on how we actually have interests in qualities basic to the emotions and how we find satisfaction within the very modes of participation that consciousness allows and extends. ${ }^{9}$

\section{Nietzsche on the 'aesthetic state'}

That emotion, affect, feeling, and so on are of high importance to Nietzsche hardly needs to be said, and it will be agreed also that they play no single role in his thought but rather several different roles. The one that matters for present purposes is his conception, which is to the fore in his The Birth of Tragedy (BT) but which, like much in that work, endures into his later writings in one form or other, that the Good must be conceived as involving, if not as consisting in, a particular kind of affective state. Exactly how close the connection is will not matter for my purposes; my focus is only on Nietzsche's idea that states of passion can instantiate value.

The famous formula in $B T$, that the world is justified only as an aesthetic phenomenon, is naturally read as referring to the experience of objects as having aesthetic qualities, and on the face of it this must indeed be what Nietzsche is saying: it is what he thinks the Homeric Greeks were so good at - giving the world, above all themselves, an Apollonian appearance - and the task of shaping phenomena artistically, through selective vision and perspectival modification, returns as a central theme in Gay Science.

But the other half of the famous equation which goes to form tragedy, the Dionysian, has to do not with the way that aesthetic appearances of objects conditions our affects, but with an internally generated state, which Nietzsche calls Rausch, variously translated as rapture, ecstasy or intoxication, and which in its 'pure' form abolishes world-

\footnotetext{
${ }^{8}$ Altieri, The Particulars of Rapture, 22.

${ }^{9}$ Altieri, The Particulars of Rapture, 25.
} 
awareness altogether, and indeed the self or at least self-consciousness. Nietzsche's metaphysics of the Dionysian, which purport to tell us what grounds our capacity for Rausch, can be left aside here. What is of importance is that Nietzsche supposes that, in the experience of tragic art and in the form of life which it promotes, the spectatorial and Dionysian standpoints combine, allowing self-apprehension and the internal expression of psychological force to form an essential unity. Nietzsche's term for this condition, borrowed from Schiller, is 'the aesthetic state', der aesthetische Zustand, and there are striking passages in the late Nachlaß which talk of an overflowing of energy into vision, an apprehension of the world which in turn restimulates the subjective forces that underpin it. ${ }^{10}$ It is accordingly tempting to propose a rewriting of Nietzsche's thesis in $B T$, so that it reads: The world is justified only for and to a subject who enjoys the aesthetic state. Or more strongly, and bringing Nietzsche even closer to Schiller: Only one who is in the aesthetic state, can justify, hence affirm, their own existence.

This assimilation of the Good to the aesthetic state (whether whole or partial) is radical and original. In sketches for $B T$ and at one point in the text Nietzsche itself hints that it might be considered a form of happiness, ${ }^{11}$ but its value is not hedonic in the usual sense - it is not even clear that the state is on balance pleasurable. And in contrast with Schiller, Nietzsche does not think that the aesthetic state is mandated by, or derives its significance from, the needs of our power of reason, the requirements of morality, or the necessity of uniting Freedom and Nature. Nietzsche's idea is that the aesthetic state, in addition to sustaining itself in a causal or psychological sense, is also axiologically selfsufficient - if we have it, then we need nothing more. And what gives it a special advantage in cultural circumstances where reflection has become corrosive, is that it presupposes no theoretical commitments. ${ }^{12}$

\footnotetext{
${ }^{10}$ Writings from the Late Notebooks, ed. R. Bittner, trans. K. Sturge (Cambridge: Cambridge University Press, 2003), no. 9[102], 159-160 ('Aesthetica').

${ }^{11}$ See 'The Dionysiac World View', in The Birth of Tragedy and Other Writings, trans. R. Speirs, ed. R. Geuss and R. Speirs (Cambridge: Cambridge University Press, 1999), 131, regarding Aeschylus' unification of happiness with divinity and justice, and 132 regarding the 'peace of happiness in misfortune' in Sophocles. And BT §17: in Dionysiac ecstasy, 'this delight is indestructible and eternal. Despite fear and pity, we are happily alive [Trotz. Furcht und Mitleid sind wir die glücklich-Lebendigen], not as individuals, but as the one living being, with whose procreative lust we have become one' (The Birth of Tragedy and Other Writings, trans. R. Speirs, ed. R. Geuss and R. Speirs (Cambridge: Cambridge University Press, 1999), 81). Thereafter in $B T(\$ 18,86)$ - as in his mature writings - the concept of happiness is associated derogatorily with Socratic optimism.

${ }^{12}$ Belief or at any rate ideation does enter on Nietzsche's account - Aeschylus and Sophocles each had a moral metaphysics, and the Greeks conceived themselves as viewed
} 
Given the peculiarity of this highly unorthodox conception of the Good, we might ask how Nietzsche arrived at it and what its rationale might be, and here it is helpful to go back to Schopenhauer.

Alongside the main line of argument in The World as Will and Representation are numerous remarkable passages, which flag the way in which his metaphysical picture resonates with human life as lived, and two of these can I think be regarded as supplying Nietzsche with building blocks for his conception of the aesthetic state as (a key component of) the Good.

The first, from Book I, is Schopenhauer's conception of our double existence. Schopenhauer tells us that, alongside our perceptually given surroundings, we lead a 'second life' in concepts, thanks to our power of reason: because we can abstract from what is immediately given, we can, as he puts it, take a 'panoramic view of life as a whole', and contemplate it with equanimity in a way that animals cannot:

So it is noteworthy, indeed marvellous, that we human beings always lead a second, abstract life alongside our concrete life. In the first we are subject to all the storms of reality and are prey to the influence of the present: we must strive, suffer and die, just as animals do. But our abstract life, as it appears before us in rational contemplation, is the calm reflection of the first life and the world it is lived in [...] In this realm of peaceful deliberation what had previously possessed us completely and moved us deeply, now appears cold, colourless and strange to the eye: here we are simply onlookers and spectators. In this retreat into reflection we are like actors who have played our scene, and now take our seats among the audience before we have to return to the stage; anything may now happen on the stage, even the preparation of our own death, and, looking out from the audience, we view it with equanimity; but then we return to act and suffer as we must. ${ }^{13}$

The second life overlaid on our concrete existence is, Schopenhauer thinks, decisive for what we are able to affirm in practical life: it is what allows us to, for example, sacrifice our lives for a principle or an ideological cause.

from Olympus - but as a precipitant and vehicle for the realization of an existential strategy without any doxastic foundation.

${ }^{13}$ A. Schopenhauer, The World as Will and Representation, Vol. I, trans. and ed. J. Norman, A. Welchman and C. Janaway (Cambridge: Cambridge University Press, 2010), Bk. 1, §16, 111-112. 
The other element in Schopenhauer is his idea of an unaccountable weight, or gravity, suffusing the world - unaccountable, that is, in terms of 'the world as representation', and which consequently readies us for the transition to the world as will. This passage comes from the opening of Book 2 of the work:

We will be particularly interested in discovering the true meaning of intuitive representation; we have only ever felt this meaning before, but this has ensured that the images do not pass by us strange and meaningless as they would otherwise necessarily have done; rather, they speak and are immediately understood and have an interest that engages our entire being $[\ldots \mathrm{W}]$ hat goads us to further research is simply the fact that we are not satisfied with knowing that we have representations [...] We want to know the meaning of those representations: we ask if this world is nothing more than representation; in which case it would have to pass over us like an insubstantial dream or a ghostly phantasm, not worth our notice; or in fact whether it is something else, something more, and if so, what this could be. This much is certain: what we are looking for would have to be wholly and completely different from representation. ${ }^{14}$

Jointly these two items set the scene for Schopenhauer's pessimism. Without the weight supplied by Wille, the spectacle that passes before us would be rational, transparently selfexplaining - it would be in conformity with the Principle of Sufficient Reason, as Schopenhauer understands it - but meaningless, or no more meaningful than a dream; with the weight added, however, it becomes unendurable, on account of the horrors that it presents us with and the preponderance of pain over pleasure within it. Caught between the unbearable lightness of being and its equally unbearable gravity, the only option is lifedenial.

Nietzsche, as I reconstruct him, takes over Schopenhauer's notions (first) that our vision is bifocal, allowing us to overlay a 'second life' of our own contrivance on what life concretely presents us with, and (second) that will is what gives things their ponderous reality. But Nietzsche thinks it possible for these two factors to conjoin in a way that Schopenhauer did not envisage, and which provides for a non-pessimistic solution to the existential problem that, Nietzsche believes, Schopenhauer correctly identified. In the aesthetic state, Nietzsche supposes, we are able to harness Wille and convert the effects of

\footnotetext{
${ }^{14}$ The World as Will and Representation, Vol. I, Bk. 2, §17, 119, 123.
} 
gravity, which would otherwise drag us down into life-denial, into a life-affirmative power of flight; and what makes this possible is precisely our appreciation of the irreality of what Schopenhauer calls the world as representation. The resulting state may be compared, in a simile that finds Nietzsche clearly compelling, to a waking dream (in which we desire to dream on $:{ }^{15}$ because we are fully awake, and so can engage our wills in full selfconsciousness, the dream can have substance and, as Schopenhauer put it, hold 'an interest that engages our entire being'; while our knowledge that whatever might ensue has in itself no greater reality than a dream immunizes us against catastrophe and (in a strange way) makes suffering not matter; so the two conditions that Schopenhauer suggests that we merely alternate between in schizoid fashion - either animal immersion in concrete practical life, or disengaged contemplation - are fused into a single state, in which we are at once actors and audience. What Schopenhauer describes as a 'ghostly phantasm not worth our notice' is elevated by Nietzsche to a positive fiction, of which we take ownership, and in which we stand to suffer no loss. ${ }^{16}$ And what according to Nietzsche shows that this configuration is possible is tragedy (and Wagner's music-drama).

The genius of Nietzsche's strategy in $B T$ consists, then, in engaging with Schopenhauer in his own terms: Nietzsche accepts Schopenhauer's excruciatingly strippeddown view of our fundamental situation yet reverses his pessimistic conclusion, without introducing anything that might be charged with begging the question.

There is more in $B T$ that supports the idea that Nietzsche regards passion of the right kind, springing from a source within the subject, as a good in itself.

Hamlet is described in Section 7 of the work as exhibiting one facet of Dionysian man. He is the Dionysus-worshipper who finds himself, post-Rausch, in the cold grey dawn, nauseated by existence and paralyzed by knowledge. ${ }^{17}$ This last characteristic of, as Coleridge puts it, 'ratiocinative meditativeness' ${ }^{18}$ - the Hamlet sicklied 'oer with the pale

\footnotetext{
${ }^{15}$ See $B T, \S 1,15-16$, and The Gay Science, ed. B. Williams, trans. J. Nauckhoff (Cambridge: Cambridge University Press, 2001), §59, 70.

${ }^{16}$ That the state of mind is irrational is, of course, beside the point. We are seeking a solution to the problem posed by an irrational situation; no solution that was not irrational could be life-affirmative.

${ }^{17} B T, \S 7,40$. See also Ecce Homo, 'Why I am So Clever', §4, and Nietzsche Contra Wagner, 'The Psychologist', §3, in The Anti-Christ, Ecce Homo, Twilight of the Idols: And Other Writings, ed. A. Ridley and J. Norman, trans. J. Norman (Cambridge: Cambridge University Press, 2005), 91 and 279-280. Some remarks, however, characterize Hamlet as a mere modern: see Werke. Kritische Gesamtausgabe, 25 vols., ed. G. Colli and M. Montinari (Berlin: De Gruyter, 1967-2006), III-3.293, V-2.516, VII-1.625, and VII2.153.

${ }^{18}$ S. T. Coleridge, Complete Works, Vol. IV, Lectures upon Shakespeare and Other Dramatists (New York: Harper, 1858), 154. It is of note (and speaks in Nietzsche's favour)
} 
cast of thought - is highly familiar, and it raises the question of why Nietzsche should draw any association of Hamlet with the Dionysian. If Hamlet is a reflective modern, tending to nihilism, then in terms of how the existential possibilities are defined in $B T$, he would seem to count as a descendant of Socrates, not Aeschylus and Sophocles, perhaps even as proto-Schopenhauerian. The question, then, is what, in Nietzsche's terms, makes it possible for Shakespeare to build a tragedy around such a figure, given that Nietzsche of course rejects Schopenhauer's interpretation of the work as a consummate lesson in resignation. ${ }^{19}$

Nietzsche does not spell it out, but there is a way in which Hamlet exhibits Dionysianism. ${ }^{20}$ Also embedded in his psychology, and serving as a counterweight to his disposition to ironize, is Hamlet's unfeigned passion for passion: evidenced by his exhilaration at being harrowed with fear and wonder by his father's ghost, his delight at the arrival of the Players and importunate demand for a 'passionate speech', his zeal in manufacturing situations which raise the emotional temperature, and so on. This will-topassion, at the other extreme from Hamlet's meditative excess, creates the tension in his personality required for modern tragedy. What therefore makes Hamlet for Nietzsche not a mere anticipation of late modern pessimism but also or instead a Dionysian figure is, then, his valorization of affective life for its own sake: one part of him accepts Schopenhauer's conclusions, but another part shares with the tragic Greeks the knowledge that what is of supreme importance is that the movement of affect should take place at any cost, whether its grounds are real or fictive. If the measure of passion lay outside it, then the course of the play, in relation to the revenge motive and execution of justice, could not be regarded by Hamlet, or us, as anything more than an abortive farce, whereas in fact it ends with selfaffirmation - Hamlet, like Othello, is able to hear the Good resonating in his own destruction (and so instructs Horatio to tell his tale, as does Othello to Lodovico). This is why Yeats can say that, 'With the great stage curtain about to drop', Shakespeare's tragic

that Coleridge strains to integrate Hamlet's intellectuality with his 'overbalance of the imaginative power', that is, to explain why Hamlet's 'meditations on the workings of our minds' - his interest in 'mental philosophy' - should produce a lack of 'equilibrium between the real and the imaginary worlds' (136-137).

${ }^{19}$ See T. Stern, 'Schopenhauer's Shakespeare: The Genius on the World Stage', in Shakespeare and Continental Philosophy, ed. J. Bates and R. Wilson (Edinburgh: Edinburgh University Press, 2014), 56-75. Nietzsche is, one might say, stealing Hamlet from Schopenhauer, turning against Schopenhauer what he held up as conclusive proof. ${ }^{20}$ Hesitation is due in claiming that what follows tracks Nietzsche's thought, but some supporting evidence can be found in the references to Hamlet given above and in a passage on Macbeth which I come to shortly. 
protagonists discover 'Gaiety transfiguring all that dread' - 'Heaven blazing into the head.' 21

A similarly affirmative, passion-based view emerges in a passage in a later work of Nietzsche's, which leaves behind the metaphysics of $B T$ :

Whoever thinks that Shakespeare's theatre has a moral effect, and that the sight of Macbeth irresistibly repels one from the evil of ambition, is in error: and he is again in error if he thinks that Shakespeare himself felt as he feels. He who is really possessed by raging ambition beholds this its image with joy; and if the hero perishes by his passion this precisely is the sharpest spice in the hot draught of his joy [...] Do you suppose that Tristan and Isolde are preaching against adultery when they both perish by it? This would be to stand the poets on their head: they, and especially Shakespeare, are enamoured of the passions as such [verliebt in die Leidenschaften an sich sind] [...] The tragic poet has just as little desire to take sides against life with his images of life! He cries rather: 'it is the stimulant of stimulants, this exciting, changing, dangerous, gloomy and often sun-drenched existence! It is an adventure to live - espouse what party in it you will, it will always retain this character!'22

This recalls what we saw Altieri say about Othello. The reflexive, affirmative character of the moment of recognition in Shakespearean tragedy - Aristotle's anagnorisis - is brought out if we draw comparison with Racine's Phèdre, where passion is merely ethically negative, an obstacle in our pursuit of the Good. The passion which drives the course of the play, Phèdre's incestuous desire for her stepson Hippolytus, is represented in beautiful Alexandrines, but the verse reserves its beauty for itself rather than transmitting it to its object. We recognize Phèdre as noble, in so far as she raises herself up in opposition to her desire, but Phèdre is not allowed by Racine to find aesthetic value in passion, and so cannot affirm her own fate. In this Jansenist work, there is no occasion for the selfaffirmation achieved by the protagonists of Shakespearian tragedy. ${ }^{23}$

Now there is still quite some way to go from what I have just been talking about, to the idea advanced at the beginning. Hamlet and Macbeth are not run of the mill subjects of

\footnotetext{
${ }^{21}$ From 'Lapis Lazuli', in Last Poems.

22 Nietzsche, Daybreak, §240, ed. M. Clark and B. Leiter, trans. R. J. Hollingdale (Cambridge: Cambridge University Press, 1997), 140-141.

${ }^{23}$ I owe these observations concerning Phèdre to Anthony O'Hear.
} 
passion, and life as viewed through the lens of tragic art is a special case. So the question is: Even if a potential for aesthetic self-experience is realized in tragedy, why should anything more general concerning the passions be concluded from this?

\section{Aesthetics without objects?}

This takes us to the (obvious) objection: Granted that there may be an interest in affect of the sort I have indicated, which differs from ethical and cognitive interest, and which is too complex and freighted with meaning to count as mere appetite, why call it aesthetic (except, perhaps, faute de mieux)? The concept has after all so many connotations missing from the case at hand. To begin with a rudimentary point, even if we waive the strong Kantian requirements of disinterestedness and universal validity, aesthetic interest is directed towards an object of appreciation, which we can explore from different angles. Passions as given in first-order experience are obviously not like this. We do talk of episodes of feeling as, for instance, stopping us in our tracks, or as eluding our attention, but the objectuality of such mental inner items, in contrast with pains, itches and other somatic objects, ${ }^{24}$ is of a vanishing sort. Not even the most adept student of Proust or Valéry can perform within the stream of consciousness the mental acrobatics needed to fix la vie intérieure in the manner of a pigmented canvas or the words on a page. ${ }^{25}$ The problem, then, is that, although passion may exhibit sensational qualities by virtue of its felt immediacy, as do pleasure and pain, and in addition may recruit to itself characteristic patterns of thought, it lacks the robust objectuality needed for it to command authentically aesthetic interest.

There must in addition be a suspicion - stemming from the way in which, from the beginning, by starting with Altieri and following with Nietzsche, I have allowed art to take the lead - that the idea I have been touting (contrary to what I said at the outset) confuses the aesthetic satisfaction taken in the artistic representation of affect, with the bare relation of psychological ownership, the mere having of it: in other words, that talk of an aesthetic dimension to passion confuses the way in which it can be presented or symbolized externally, with an intra-subjective relation. It might be added that, though Nietzsche may indeed have recommended, in his early aestheticist days, that we view our lives, inclusive

${ }^{24}$ See S. Irvin, 'Scratching an Itch', Journal of Aesthetics and Art Criticism, 66, 2008, 2535 .

${ }^{25}$ The point is well made by J. N. Findlay in 'The Perspicuous and the Poignant: Two Aesthetic Fundamentals', The British Journal of Aesthetics, 7, 1967, 14. 
of our mental episodes and stream of consciousness, as if they were constituents of artworks, this is a far cry from showing that any aesthetic dimension is in fact constitutive of them in the way I proposed at the outset.

In brief response to this second objection, it is worth recalling that the interest we take in art itself stands in need of explanation, and that a great many of the classic attempts to explain why art matters, since the demise of German Idealism and the waning of cognitive theories of art, refer in one way or another to emotion, the value of which they take for granted. To take some well known examples: Clive Bell tells us that the value of Significant Form lies in the distinctive 'aesthetic emotion' that it induces, Collingwood appeals to expression of emotion in order to distinguish fine art from mere craft, and Suzanne Langer describes art as the symbolic language of feeling. And in each of these cases explanation comes to an end with the affective state that art is said to induce: according to Bell, nothing can be said about what makes 'aesthetic emotion' intrinsically valuable; Collingwood tells us only that the artistic expression of emotion implies its 'clarification', a notion which he cannot be said to elucidate; ${ }^{26}$ and for Langer it is in effect axiomatic that presenting the form of feeling has value. My point, then, is not that these are bad theories of art, but that they pass the buck, and that this gives reason for regarding art as amplifying and exploiting a value which affect has antecedently. This at any rate is, as we have seen, Nietzsche's strategy in $B T$, and the basis of Altieri's claim that the arts provide privileged access to the nature of affect in general.

The first objection however requires a longer and fuller answer. A start can be made if we consider Kant's account of what is needed to differentiate the aesthetic in the sense of the beautiful, from the merely agreeable. The problem of taste, familiar from Hume, is that only a feeling of pleasure can ground a judgement of taste, yet the content of judgements of taste is not simply that the object has given or is capable of giving us pleasure. On this basis Kant argues that a complex structure must be implicit in the species of pleasure peculiar to beauty. Kant puts this by saying that judgements of beauty, though grounded on feeling, are also 'reflective' (the same goes for the sublime). As Kant develops this model, the key to the aesthetic lies not directly in the properties of the object - which on Kant's account is reduced to a mere precipitant or occasioning cause - but in the

\footnotetext{
${ }^{26}$ Though an attempt at elucidation is certainly made: see R. G. Collingwood, The Principles of Art (Oxford: Oxford University Press, 1958), 229-233, 238-239, 274-275, 281-283. The problem lies in Collingwood's concentration on the idea that it is only by means of their artistic expression that the emotions which constitute artworks can be known, as if this cognition sufficed to account for artistic value, without elucidating the 'knowledge' in question.
} 
internal configuration of the subject: experience of beauty involves (first) a specific internal relation between the subject's mental powers, and (second) the subject's own cognition of this very relation through sensation and judgement; and these two levels within the subject reinforce one another, with the result that we 'linger' indefinitely over the object. Leaving aside all of the details, the point is that, according to Kant and as in any case seems plausible, in order for an object to be registered as aesthetically significant rather than merely agreeable or disagreeable, special subjective conditions need to be satisfied, which go beyond the reference to an object involved in a perceptual state or the representational content of a propositional attitude. The idea I now want to explore is that, appearances to the contrary perhaps, there is reason for thinking that some such structure is found in passion. It is nothing like what Kant postulates to account for our feeling for the beautiful, but it qualifies nonetheless as an internal structure, enough of one to make sense of the idea that emotions can present aesthetic appearances.

\section{The internal structure of emotion}

Attempts to construct general philosophical theories of emotion proceed naturally on the assumption that they are in some way compounded out of the type of content which common sense psychology makes available in ascriptions of propositional attitudes, along with feelings or sensations. What makes this reasonable is of course the necessary connection of emotion with, on the one hand, beliefs and desires, and (if these are something different) with evaluative judgements or 'pro-attitudes', and, on the other, their connections with pleasure and pain. This yields a direct explanation of the standing connection of emotion with action - the fact that specific emotions dispose us to act in specific ways - and it also allows sense to be made of their normative appraisal (bad emotion betrays vicious desire, inappropriate emotion reflects false belief, etc.). Whence the project of attempting to specify, for each emotion kind, what particular beliefs and desires must be in place for it to ensue (what beliefs are needed for pride, how guilt and shame differ, and so on).

The dialectic which then ensues is familiar. The hard question is what needs to be added to the complex of beliefs and desires which comprise the nucleus of an emotion in order for it to form a genuine synthetic unity. It seems we face a choice between identifying the missing supplementary item either with a further judgement, the content of which goes beyond the belief-and-desire conditions of emotion, or with something nonjudgemental and phenomenal, perhaps bodily. The former yields the puzzle of what the 
content of the supplementary judgement might be, which threatens to take us full circle, and in any case seems insufficient to account for the phenomenal aspect of emotion. The latter leaves mysterious the transition from propositional content to the phenomenal item, as well as the nature of the latter, in so far as it seems plainly unsatisfactory to prise apart the thought-content of an emotion from the feeling that manifests it.

If this is a fair summary of the difficulty facing theories of emotion - how can we make emotions philosophically intelligible without reducing them to mere aggregates? then the following train of thought becomes attractive. If the problem - or rather the first of them, for in fact two have emerged - is that emotion, while having an intimate connection with the content available in belief and desire, does not seem constructible out of it, then we must look for it elsewhere. And if the second problem is that emotion combines contentual and phenomenal elements in an essential unity, then we must look for a kind of content which will make that combination intelligible, that is, a kind of content which by its nature calls for phenomenal expression.

This is a tall order, and what I am going to suggest is limited in scope and geared to showing that there is a way of responding to these demands which makes sense of the idea that passion may exhibit an aesthetic dimension. ${ }^{27}$

In a classic paper, Richard Wollheim argued that the mind should be understood as operating under two 'images of itself'. ${ }^{28}$ It conceives itself, on the one hand, as an extensionless point, moving along the single axis of time. Such is the character of, for example, reflective deliberation. But it conceives itself also, in other respects, as a place, that is, as having a certain extension, which allows it to act as a container, marked by boundaries, such that it can represent itself as either including or excluding (and furthermore as either incorporating or expelling) particular objects, of some inevitably peculiar sort. The mind's conception of itself as a place, Wollheim supposes, develops originally out of infantile experience of the body, on which it remains to some degree modelled throughout our lives - it is, in a phrase he borrows from Freud, a 'bodily ego' ${ }^{29}$

The full theoretical interest of this conception, for Wollheim, is that it provides for those forms of psychoanalytic theory which postulate an inner world, populated by figures

\footnotetext{
${ }^{27}$ What follows resumes and extends my argument in 'The Nature and Source of Emotion', in Art, Mind and Psychoanalysis: Essays in Honour of Richard Wollheim, ed. J. Hopkins and A. Savile (Oxford: Blackwell, 1992), 35-54.

${ }^{28} \mathrm{R}$. Wollheim, 'The Mind and the Mind's Image of Itself', International Journal of Psycho-Analysis, 50, 1969, 209-220; repr. R. Wollheim, On Art and the Mind (Cambridge, MA: Harvard University Press, 1974), 31-53.

${ }^{29}$ See R. Wollheim, 'The Bodily Ego', in R. Wollheim and J. Hopkins (eds.), Philosophical Essays on Freud (Cambridge: Cambridge University Press, 1982), 124-135.
} 
formed through phantasy and modified in accordance with psychological need in ways that contrast with the conscious, rational organization of mental life. Exemplifying this conception are the notions, which have found their way into folk psychology, of projection and identification: I get rid of a bit of myself by placing it outside me, or I relate to some object, or person, outside me as if to something internal to my mind. From the conclusion of Wollheim's essay:

It is in large part due to the insights, to the experience of psychoanalysis that today we have a view, at once larger and more complex, of this matter [...] I have talked of our conception of the mind as tinged with spatiality. I have set this beside other conceptions of the mind heavier with history and also heavier with spatiality. All such conceptions derive ultimately from an assimilation of the mind to the body, of mental activity to bodily functioning, of mental contents to the parts of the body. So the mysterious union of mind and body occurs also at a stage farther back than the traditional philosophers apprehended. It is not merely that we are at home in our body: we are at home in our mind somewhat as in a body. ${ }^{30}$

Acceptance of the strong Kleinian form of psychoanalytic theory defended by Wollheim, though in my own view credible and substantiated, is not required for present purposes. ${ }^{31}$ What matters is the vaguer idea that there is a level of non-conscious mental content which operates under the conception of the mind-as-a-place, or of which we can say, at least, that it is experienced as behaving in such terms; or, to weaken the claim still further, a kind of content which we can get hold of, avow and ascribe, only by using spatial and bodily metaphors. And it is content of this sort which, I suggest, has to be assumed if we are to make full sense of the difference between emotion and other kinds of mental state. The claim is not that this content comprises the whole of an emotion - which would remove it from the network of propositional attitudes - but that it lies at its root, supplying the basic stuff which comes to be informed by belief and desire and worked up into selfconsciously recognizable, normatively evaluable mental states. To put the basic idea in

\footnotetext{
${ }^{30}$ Wollheim, 'The Mind and the Mind's Image of Itself', 219 (On Art and the Mind, 53).

${ }^{31}$ What follows coheres with much of the extended account that Wollheim gives in On the Emotions. Two differences worth pointing out are that Wollheim puts weight on the notion of an 'attitude' or 'orientation', distinguished by its aetiology, whereas I instead talk of 'content'; and that Wollheim makes it a necessary condition of emotion that it should originate in an experience of frustration or satisfaction of a desire, whereas I leave it open that emotion might be an original mental formation that is independent from and may even antedate desire.
} 
loose, non-psychoanalytic terms: In the case of any well-formed passion of the sort than can act as a motive, such as Othello's jealousy, there has to be something that is going on inside the mind, something the mind is up to. And this 'going on' is registered in conscious episodes of feeling - which we may regard as constituting the meeting point of the mind's two self-images, the extensionless point of self-consciousness and the mind's image of itself as extended. Hence the involvement of the concept of movement in the characterization of emotion: to have an emotion in the face of this-or-that, is to be moved by it, but the real external object does not of course literally move the mind, rather it elicits a movement of its own within the mind, thus in relation to itself. ${ }^{32}$ Hence, also, the curious fusion of passivity and activity characteristic of affective states, which we on occasion describe as assailing us like physical forces, but can never regard as doing so - compare physical pain - without our participation. ${ }^{33}$

Some recent writing on emotion, seeking to rehabilitate them for rational life, has argued that it should be regarded as an adjunct to practical and theoretical reasoning - for example, as a psychological function that converts evaluative beliefs into action dispositions, or that accelerates and gives direction to inference-making. ${ }^{34}$ There is no need to deny that emotion is able to function in these ways in order to doubt that such approaches provide a full characterization of the total work that emotion does in the mind. No less central is the resistance that emotion is capable of mounting to reasoning. ${ }^{35}$ The essential point here, reflected in the perennial attractiveness of the notion that emotion has a 'logic' of its own, ${ }^{36}$ is that emotion has the power not simply to block the deliverances of practical and theoretical reason in the manner of a natural force, in the way that sheer physical exhaustion may stultify a resolution, nor simply to cause them to fail to be realized, as occurs in textbook akrasia, but to seemingly invalidate them, to make reasoned judgement appear to have missed the point: passion can be experienced as cancelling or

\footnotetext{
${ }^{32}$ Even where no movement-inducing object can be located, still we regularly conceive a passionate subject as in some way 'off centre' or displaced. We say: He didn't mean it, he was emotional: he was not himself. ('If Hamlet from himself be ta'en away, ... Then Hamlet does it not.')

${ }^{33}$ We 'participate' the very moment we identify the emotion as being of a certain kind: to recognize it as such and such is to self-ascribe the relevant thoughts.

${ }^{34}$ M. Nussbaum, Upheavals of Thought: The Intelligence of Emotions (Cambridge: Cambridge University Press, 2003), leans strongly in this direction, claiming that emotions are above all appraisals of value which comprise an essential part of human intelligence.

35 The connection is emphasized by Wollheim throughout his On the Emotions, and is also highlighted in R. Moran's well-known 'The Expression of Feeling in Imagination', Philosophical Review, 103, 1994, 75-106.

${ }^{36}$ See for example P. Redding, The Logic of Affect (Ithaca NY: Cornell University Press, 1999).
} 
overtaking the authority of unimpassioned principled reflection. That emotion, like desire, is able to at least seem to operate under the guise of the Good - le cour a ses raisons - is reflected in its characteristic sponsoring of imaginative scenarios intelligible to the subject centred within the emotion, with indifference to their critical reflection. The power of this apparent alternative intelligibility to undercut reason or hold it in check, is possible, I am suggesting, only if emotion brings with it its own 'way of thinking', which means that we must suppose it to have its own source of content. ${ }^{37}$

This conception of emotion is not without historical precedent. I said that Nietzsche does not offer much by way of conceptual analysis of passion, but there are other figures in whom we do find elements of the view just sketched. Here is a statement from Spinoza, concerning the emotions in general:

Pleasure, pain, and consequently the emotions that are compounded of these or derived from them are passive emotions (Sch. Pr. 11, III). Now we are necessarily passive (Pr. I, III) insofar as we have inadequate ideas, and only insofar as we have inadequate ideas are we passive (Pr. 3, III). That is to say (Sch. Pr. 40, II), we are necessarily passive only to the extent that we form mental images [imaginamur], i.e. (Pr. 17, II and Sch.) to the extent that we are affected in a way that involves both the nature of our own body and the nature of an external body. ${ }^{38}$

Illustrating this conception, here is Spinoza's treatment of jealousy:

This hatred towards the object of one's love, joined with envy, is called Jealousy [zelotypia], which is therefore nothing else but 'vacillation arising from simultaneous love and hatred accompanied by the idea of a rival who is envied'. $[\ldots \mathrm{H}] \mathrm{e}$ who thinks of a woman whom he loves as giving herself to another will not only feel pain by virtue of his own appetite being checked but also, being compelled to associate the image of the object of his love with the sexual parts of his rival, he will feel disgust for her. ${ }^{39}$

Spinoza's theory of 'inadequate ideas', and of the formation of 'mental images' determined by the way in which they echo bodily states, along with his conception of the laws that

\footnotetext{
${ }^{37}$ As I hope to have intimated: to recognize this fact, and even to accord it value, is not to endorse the thesis of an actual alternative rationality.

${ }^{38}$ Ethics, Part III, Proposition 56, Proof, 307.

${ }^{39}$ Part III, Proposition 35, Scholium, 295-296.
} 
'compel' their peculiar modes of combination, is remarkably close to the view of passion suggested by Wollheim's psychoanalytically-inspired discussion.

As the quotations show, Spinoza famously supposes that human nature yields to a kind of quasi-geometrical decompositional analysis, a notion that reflects his rationalism but, it is fair to say, does not have the ring of truth. To correct for this, without overturning Spinoza's insight, here is a passage from Bergson's Time and Free Will, which reminds us that passions present themselves not as aggregates but as essential unities:

This overwhelming of the immediate consciousness is nowhere so striking as in the case of our feelings. A violent love or a deep melancholy takes possession of our soul: here we feel a thousand different elements which dissolve into and permeate one another without any precise outlines, without the least tendency to externalize themselves in relation to one another; hence their originality. We distort them as soon as we distinguish a numerical multiplicity in their confused mass [...] The feeling itself is a being which lives and develops and is therefore constantly changing; otherwise how could it gradually lead us to form a resolution? Our resolution would be immediately taken. ${ }^{40}$

The passage puts into sharp relief the way passion is experienced and conceived, in some of its forms, as a semi-substantial organic whole which transcends and grounds our dispositions to episodes of feeling. This 'realist' conception is instanced, Bergson is telling us, whenever an episode of feeling is taken as revealing the mind to itself noninterpretatively, i.e., whenever a feeling is recognized as being of such-and-such an emotion-kind.

If this is right, then we begin to understand why passions have a volume and substantiality not exhibited by other kinds of mental state. That affective phenomenology has a depth and interior thickness that perceptual experience, and merely discursive episodes in mental life, do not have, grants passions an aesthetic dimension: we apprehend

\footnotetext{
${ }^{40}$ Bergson, Time and Free Will, 132-133. The way I have cited Bergson is intended to show how he supposes emotion to exemplify an interpenetrative, qualitative, nonnumerical multiplicity, reaching down to 'the deeper strata of the self' (136), but that edits out his repudiation of all quasi-spatial analysis of mental content. In so far as Bergson holds that the organic unity of emotion subsists exclusively in the dimension of 'duration', he must reject the psychoanalytic-Spinozistic model I describe. (That said, it is worth noting Bergson's concession that a novelist might employ pseudo-spatial juxtaposition of the constituents of emotion indirectly, in order to bring 'us back into our own presence', 134.)
} 
within them a unitary composite with a scenic character which, whether or not it eventually comes to control belief and the will, as it does in Othello's case, is capable of holding an interest that, to use Schopenhauer's phrase once again, engages our entire being.

\section{Obscurities}

Let me end by acknowledging two matters in particular which would need to be addressed if the main idea were to be made more definite, and adding two very brief comments on the way I have left things. ${ }^{41}$

My title contains an ambiguity, which I have exploited, and which is present in the passages I quoted from Altieri and indeed throughout his book. To resume the objection raised earlier: There are two ideas that one might think need to be distinguished in talking of the aesthetic dimension of passion. One is that affect facilitates an apprehension of value by aesthetic means. The other is that we apprehend affect itself as having aesthetic value. The first says that affect, due to its aesthetic character, allows something other than itself to be apprehended as having value of some species. The second says that affect is the very thing that bears the aesthetic value apprehended. In the former case, the aesthetic dimension of affect functions as, so to speak, a window onto value, while in the latter it is not the window but rather what is seen through it. ${ }^{42}$

A further issue left unresolved is that I have said nothing directly about what aesthetic value comprises in the context of the passions. To what extent does it turn on formal relations, and in what ways is it bound up with the content of experience and with other, non-aesthetic values? Both seem possible. When affective states are considered in terms of the sorts of features that lead Langer to talk of feeling as necessarily having form - their varying intensity, plasticity, dynamic properties and so on - then we see scope for the former, while in the Othello case, as Altieri presents it, content is clearly dominant. ${ }^{43}$

Now the fact that the issues just mentioned are connected with long-running debates in aesthetics allows a suggestion to be made. The difficulties just described - of

\footnotetext{
${ }^{41}$ There are a great many others. I have said, for instance, nothing about what special conditions are required, what specific types of passion might especially lend themselves to aesthetic exploitation, nor about the different ways in which its aesthetic aspect may be taken up. They are among the questions with which Altieri's book grapples and, it is plausible to suggest, issues with which many major novelists - inclusive of Henry James, D. H. Lawrence, and Proust - are self-consciously concerned.

${ }^{42}$ For good measure, there is a third possibility, which is simply that there is value in our being so constituted as to be capable of having such states.

${ }^{43}$ Though in fact formal properties of intensity and distance are also invoked by Altieri.
} 
disentangling form from content, and of discriminating what is aesthetic in an object from what is aesthetic in its mode of presentation, and of drawing a line between aesthetic and other species of value - are characteristic of critical discussion of literature and painting, which moves seamlessly back and forth between formal and representational features of artworks, and between the attribution of affective qualities to works of art, and the attribution of affective responses to readers and spectators. My point, then, is that if the same conceptual messiness is present in the experience of art, its appearance in the context of the passions cannot count against the idea that they have an aesthetic dimension.

Finally and in conclusion, there is scope for taking this last point a step further, in a way that brings us back to Nietzsche. The difficulty of parcelling out, in the context of aesthetically significant affect, what belongs properly to us as psychological subjects, and what belongs to objects, and of breaking up affect into form and content, is plausibly part of what so to speak locks us into the world: it creates a primitive attachment to the activity of living independent from whatever we might hope to gain from the satisfaction of desire and the fulfilment of cognitive ends. ${ }^{44}$ This, I suggest, is the Nietzschean insight that silences Schopenhauer's argument for life-denial: ${ }^{45}$ if, as Nietzsche supposes, the aestheticaffective field composes the outermost frame of evaluation, then, for any subject who is not fully anaesthetic, the possibility of value cannot thinkably be cancelled, whatever the balance of pleasure and pain within human life, and even when the aesthetic quality of passion is negative, as it is for Phèdre. ${ }^{46}$ In this way, what philosophical reflection encounters as obscurity, a frustrating impediment to analysis, becomes a saving grace.

\section{University College London}

sebastian.gardner@ucl.ac.uk

\footnotetext{
${ }^{44}$ In this connection, see R. Wollheim, The Thread of Life (Cambridge: Cambridge University Press, 1984), Chs. 8-9, regarding the primitiveness of self-concern. Also relevant is Wollheim's suggestion that one reason why death may be considered a misfortune is that it involves the extinction of phenomenology, for which our appetite is 'insatiable' (282; to be read in light of Wollheim's broad understanding of phenomenology, 239-240).

${ }^{45}$ More exactly: that at least shows why Schopenhauer's case for life-denial cannot strictly take the form of a practical argument to that conclusion.

${ }^{46}$ I am grateful to respondents in the audience at the Royal Institute of Philosophy, and at a conference on Ethics and Emotion in the Post-Kantian Tradition at the University of Southampton where an earlier version was presented, for questions and comments, and especially to Sarah Richmond and Anthony O'Hear for extremely helpful suggestions.
} 